\title{
Net Returns from Terrain-Based Variable-Rate Nitrogen Management on Dryland Spring Wheat in Northern Montana
}

\author{
Dan S. Long,* Jeffrey D. Whitmus, Richard E. Engel, and Gary W. Brester
}

\begin{abstract}
Agricultural producers can use variable-rate application technology to vary $\mathrm{N}$ fertilizer within fields. This study was conducted to estimate changes in net returns from implementation of variable-rate $\mathrm{N}$ management (VNM) on hard red spring wheat (Triticum aestivum L.) in a summer-fallow region in northern Montana. Net return from uniform N management (UNM) traditionally used by producers was compared with that from VNM in eight dryland fields between 1994 and 2004. Field experiments consisted of a replicated series of four to six $\mathrm{N}$ rates applied within strips oriented with the length of each field. Management zones (MZs) were created by dividing the fields into upper slopes, south-facing middle slopes, north-facing middle slopes, and lower slopes. Nitrogen recommendations for MZs were based on soil $\mathrm{N}$ testing and expected yields. Grain yield data were obtained using a production-size combine equipped with a yield monitor. Mean grain protein and yield were similar between VNM and UNM. Yield differences were $<223 \mathrm{~kg} \mathrm{ha}^{-1}$ and averaged only $18 \mathrm{~kg} \mathrm{ha}^{-1}$. Grain yield did not differ significantly among $\mathrm{N}$ rates within MZs. In seven of the eight sites, net returns from VNM were up to US\$27.97 ha ${ }^{-1}$ less than from UNM and were not profitable if Environmental Quality Incentive Program payments of US\$6.36 ha $\mathrm{h}^{-1}$ were considered as part of net income. Little evidence existed that VNM based on constructed MZs and predetermined $\mathrm{N}$ recommendations improves grain yields and profits or reduces $\mathrm{N}$ use in water-limited, summer-fallow systems of northern Montana.
\end{abstract}

The northern Great Plains is climatologically well suited to growing hard red spring wheat (HRSW) because of wet springs and cool dry summers. Northern Montana produces high-quality HRSW with superior milling and baking characteristics that is consistently sought by millers and bakers (North Dakota Wheat Commission, 2013). The majority of HRSW produced in this region is either milled for bread flour or blended with lower quality wheat. In many years, wheat buyers pay a premium over ordinary protein wheat to obtain spring wheat with a protein concentration (PC) between $140 \mathrm{~g} \mathrm{~kg}^{-1}(14 \%)$ and $150 \mathrm{~g} \mathrm{~kg}^{-1}(15 \%)$. Although premiums vary from year to year and are not known a priori, the highest protein premiums occur in years when the US (and world) winter wheat crop has below-average protein. Thus, producers have an economic incentive to consider the expected PC of their grain when choosing seed cultivars and fertilizer programs.

Adequate soil fertility is required to produce high-quality HRSW, and $\mathrm{N}$ is the most important nutrient for optimal grain

D.S. Long, USDA-ARS, Columbia Plateau Conservation Research Center, P.O. Box 370, Pendleton, OR 97801; J.D. Whitmus and R.E. Engel, Dep. of Land Resources and Environmental Sciences, Montana State Univ., Bozeman, MT 59717-3120; and G.W. Brester, Dep. of Agricultural Economics and Economics, Montana State Univ., Bozeman, MT 59717-2920. Received 26 June 2014. Accepted 10 Jan. 2015. *Corresponding author (dan.long@ars.usda.gov).

Published in Agron. J. 107:1055-1067 (2015)

doi:10.2134/agronj14.0331

Available freely online through the author-supported open access option. Copyright (๑) 2015 by the American Society of Agronomy, 5585 Guilford Road, Madison, WI 53711. All rights reserved. No part of this periodical may be reproduced or transmitted in any form or by any means, electronic or mechanical, including photocopying, recording, or any information storage and retrieval system, without permission in writing from the publisher. yield and PC (Engel et al., 2001). Nitrogen typically accounts for the largest percentage of a wheat producer's fertilizer inputs (National Agricultural Statistics Service, 2010). Variable-rate N management (VNM) involves the use of GPS and variable-rate application equipment to vary rates of $\mathrm{N}$ fertilizer according to spatial patterns in soil fertility and crop productivity in farm fields (Larson and Robert, 1991). Net returns from VNM can be greater than ordinary uniform $\mathrm{N}$ management (UNM) by either applying higher $\mathrm{N}$ rates onto areas of the field where yield will benefit from additional $\mathrm{N}$ or lower $\mathrm{N}$ rates to areas of the field that are less responsive to fertilizer N (Snyder et al., 1997, 1999).

Several VNM approaches have been developed to improve either cereal grain $\mathrm{N}$ use efficiency or economic returns. One approach relies on zone-based soil sampling at or near planting to determine plant-available $\mathrm{N}$ early in the growing season (Koch et al., 2004; Schepers et al., 2004; Franzen, 2008; Ferguson and Hergert, 2009). A second uses optical sensors to measure canopy reflectance to calculate a normalized difference vegetation index (NDVI) in a non-N-limiting strip and a parallel strip representative of the field (Raun et al., 2002). The ratios of the NDVIs are then used to calculate a fertilizer response index, and the variable $\mathrm{N}$ fertilizer recommendation is developed based on the yield potential of defined areas $\left(1 \mathrm{~m}^{2}\right)$ across the field landscape. Optical sensing of the crop is thought to be more economically viable than soil sampling because the latter is expensive and potentially inaccurate (Biermacher et al., 2006, 2009; Boyer et al., 2011). On the

Abbreviations: AR, autoregressive response; DEM, digital elevation model; EQIP, Environmental Quality Incentives Program; HRSW, hard red spring wheat; MZ, management zone; PC, protein concentration; UNM, uniformrate nitrogen management; VNM, variable-rate nitrogen management. 
Table I. Location, area, $\mathrm{N}$ rates, and number of replications of $\mathrm{N}$ rates for eight site-years in northern Montana.

\begin{tabular}{lcccc}
\hline \multicolumn{1}{c}{ Site-year } & Location & Area & N rates & Replications \\
\hline & & ha & $\mathrm{kg} \mathrm{ha}^{-1}$ & \\
Simpson-1994 & $48^{\circ} 50^{\prime} 3^{\prime \prime} \mathrm{N}, 109^{\circ} 54^{\prime} 4 \mathrm{I}^{\prime \prime} \mathrm{W}$ & 40 & $0,22,45,67,90,112$ & 3 \\
Simpson-1995 & $48^{\circ} 49^{\prime} 55^{\prime} \mathrm{N}, 109^{\circ} 4^{\prime} 52^{\prime \prime} \mathrm{W}$ & 23 & $0,22,45,67,90$ & 3 \\
Highwood-200I & $47^{\circ} 4 \mathrm{I}^{\prime} 42^{\prime \prime} \mathrm{N}, 110^{\circ} 29^{\prime} 57^{\prime \prime} \mathrm{W}$ & 34 & $0,37,75,112$ & 6 \\
Havre-200I & $48^{\circ} 3 \mathrm{I}^{\prime} 48^{\prime \prime} \mathrm{N}, 109^{\circ} 56^{\prime} 57^{\prime \prime} \mathrm{W}$ & 27 & $0,22,45,67,90$ & 10 \\
Malta-200I & $48^{\circ} 24^{\prime} 52^{\prime \prime} \mathrm{N}, 107^{\circ} 34^{\prime} 20^{\prime \prime} \mathrm{W}$ & 22 & $0,22,45,67,90$ & 6 \\
Malta-2002 & $48^{\circ} 25^{\prime} 53^{\prime \prime} \mathrm{N}, 107^{\circ} 35^{\prime} 7^{\prime \prime} \mathrm{W}$ & 30 & $0,22,45,67,90$ & 5 \\
Malta-2003 & $48^{\circ} 26^{\prime} 4^{\prime \prime} \mathrm{N}, 107^{\circ} 35^{\prime} 38^{\prime \prime} \mathrm{W}$ & 15 & $0,22,45,67$ & 8 \\
Malta-2004 & $48^{\circ} 25^{\prime} 57^{\prime \prime} \mathrm{N}, 107^{\circ} 34^{\prime} 50^{\prime \prime} \mathrm{W}$ & 26 & $0,22,45,67$ & 7 \\
\hline
\end{tabular}

other hand, optical sensing may be unreliable in semiarid dryland cropping systems where the crop cover is often low (leaf area index $<1.5)$ and crop growth and $\mathrm{N}$ response are controlled by the water supply (Eitel et al., 2009). Also, optical sensing approaches utilize in-season topdress application of $\mathrm{N}$ fertilizer to correct for potential $\mathrm{N}$ deficiency problems. Rainfall or irrigation is required for incorporation of fertilizer into the soil. In semiarid climates, rainfall amounts are often nominal and unpredictable, and thus topdress fertilizer $\mathrm{N}$ may remain at the surface for an extended period where it is unavailable for crop $\mathrm{N}$ uptake.

Economic studies of VNM on wheat in the semiarid western United States and Canada have been limited in number. In Montana, there was no significant economic improvement from applying fertilizer by soil type vs. by field despite the highest yielding soil types generating twice as much grain as the lowest yielding map units (Carr et al., 1991). In North Dakota, VNM based on grid soil sampling resulted in more yield of barley (Hordeum vulgare L.) than UNM but was less profitable because of added soil sampling and testing costs (Wibawa et al., 1993). In eastern Washington, Fiez et al. (1994) conducted a replicated $\mathrm{N}$ fertility trial with winter wheat at footslope, south backslope, shoulder, and north backslope positions and found net returns from variable-rate $\mathrm{N}$ application to be US $\$ 6 \mathrm{ha}^{-1}$ greater than uniform $\mathrm{N}$ application. In Saskatchewan, Beckie et al. (1997) found that variable-rate $\mathrm{N}$ fertilization returned $\mathrm{C} \$ 10 \mathrm{ha}^{-1}$ more than uniform fertilization when fertilizer recommendations were based on soil test $\mathrm{N}$ levels within zones defined from upper, middle, and lower slopes in hummocky terrain.

Crop productivity in semiarid environments is determined largely by plant-available water (Brown and Carlson, 1990) and the manner in which soil water, soil fertility, and other crop growth determining factors are distributed across the landscape (Moore et al., 1993). Yield potential is typically lower on upper slopes because of shallow, eroded soils and greater on lower slopes because of deeper soils (Gregorich and Anderson, 1985; Moulin et al., 1994). This observation forms a basis for subdividing fields into management zones (MZs) consisting of upper, middle, and lower slopes and determining plant-available $\mathrm{N}$ levels in these zones (Beckie et al., 1997; Nolan et al., 1995; Pennock and Corre, 2001; Long et al., 2002).

Few studies have investigated the profitability of VNM in summer-fallow production systems in the northern Great Plains where average growing season precipitation plus stored soil water is often $<350 \mathrm{~mm}$. The objective of this study was to compare the grain yield and economic returns of VNM and UNM based on eight site-years and soil sampling of terrain-based MZ. The results will help establish the economic feasibility of this approach for dryland wheat production in this region.

\section{MATERIALS AND METHODS}

Field Experiments

Eight field experiments were conducted on eight production fields between 1994 and 2004 near Simpson, Havre, Malta, and Highwood in northern Montana (Table 1). Fields near Simpson, Havre, and Malta were in a wheat-fallow rotation, while the field near Highwood was annually cropped in a winter wheat-spring wheat rotation. Soils are derived from glacial till parent material and are mapped as Telstad-Joplin loams (fine-loamy, mixed, superactive, frigid Aridic Argiustolls) at the Simpson and Malta sites, Bearpaw-Vida clay loams (fine-loamy, mixed, superactive, frigid Typic Argiustolls) at Highwood, and Phillips-Elloam complex (Typic Eutroboralfs-Typic Natriboralfs) at Havre.

Elevation measurements were collected at each study site using a survey-grade GPS receiver along parallel transects separated by $12 \mathrm{~m}$ in complex hummocky terrain or $18 \mathrm{~m}$ in gentle rolling terrain. Data from a base receiver were used to correct the elevation values to within $4 \mathrm{~cm}$ in both the horizontal and vertical planes. Digital elevation models (DEMs, 5-m spacing) were generated using point kriging in ArcView 3.2 (ESRI). A DEM was filtered using a combination of two $3 \times 3$ and one $5 \times 5$ low pass filters to remove linear artifacts created during the collection of elevation point data (MacMillan et al., 2000). The LandMapR terrain modeling software developed by MacMillan (2003) was used to compute 15 land classes defined by slope curvature and slope gradient (Fig. 1). Using ArcView, a land class value was extracted within $1 \mathrm{~m}$ of each yield point. Land classes were grouped into upper slopes, middle slopes, and lower slopes. The aspect module of ArcView was then used to compute the direction of slope and split the middle slopes into north- and south-facing slopes. Four MZs were established: upper slopes, south-facing middle slopes, northfacing middle slopes, and lower slopes (Fig. 2A).

The basis for the four MZs is that crop yield potential usually increases from upper to lower slopes in response to increasing soil depth and plant-available water. Slope position effects on the soil water holding capacity in glacial till landscapes of the northern Great Plains may occur when tillage erosion has resulted in soil loss and reduced rooting depth in upper slopes vs. soil deposition and increased rooting depth in lower slopes (Moulin et al., 1994; Schumacher et al., 1999). A difference between north- and southfacing slopes is that the latter receive more direct sunlight and will lose more soil water to evaporation.

Soil cores were collected at numerous, irregularly distributed points within each field. Spacing between points varied between 30 and $50 \mathrm{~m}$. Each $120-\mathrm{cm}$ core was divided into increments of 0 to 15,15 to 60,60 to 90 , and 90 to $120 \mathrm{~cm}$ at Simpson-1994 and -1995 


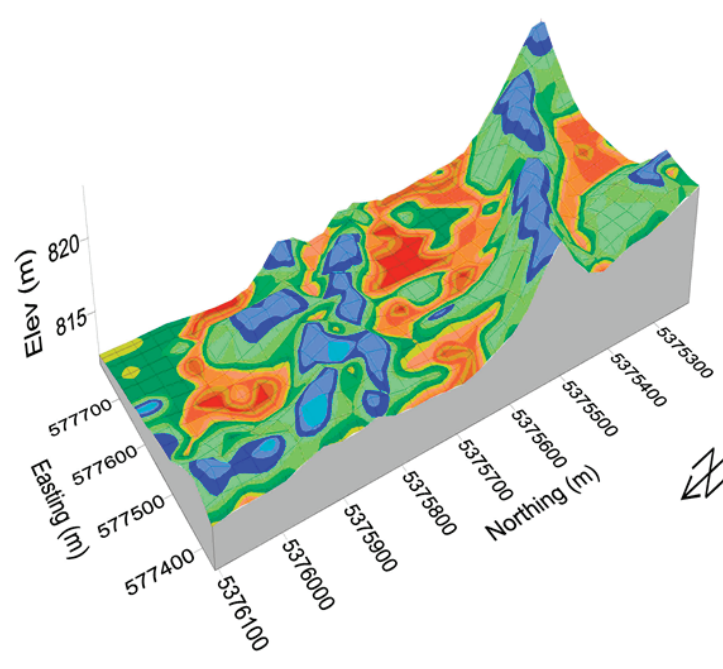

\begin{tabular}{|c|c|}
\hline Name & Position \\
\hline Level Crest & \multirow{3}{*}{ Upper } \\
\hline Divergent Shoulder & \\
\hline Upper Depression & \\
\hline Back Slope & \multirow{6}{*}{ Middle } \\
\hline Divergent Back Slope & \\
\hline Convergent Back Slope & \\
\hline Terrace & \\
\hline Saddle & \\
\hline Mid Slope & \\
\hline Foot Slope & \multirow{6}{*}{ Lower } \\
\hline Toe Slope & \\
\hline Fan & \\
\hline Lower Slope Mound & \\
\hline Level Lower Slope & \\
\hline Lower Depression & \\
\hline
\end{tabular}

Fig. I. Block diagram of the Havre-200I site with overlay of 15 land classes that were computed using the terrain modeling procedures of MacMillan et al. (2000). Map legend shows the name of each land class and its associated slope position.

and Malta-2002. Cores were collected to $90 \mathrm{~cm}$ and divided into 0 to 30,30 to 60 , and 60 to $90 \mathrm{~cm}$ at Highwood-2001 and 0 to 15,15 to 60 , and 60 to $90 \mathrm{~cm}$ at Havre-2001 and Malta-2001. At Malta2003 and -2004 , cores were collected to $60 \mathrm{~cm}$ and divided into 0 to1-5 and 15- to 60-cm increments. Soil samples were analyzed for $\mathrm{NO}_{3}-\mathrm{N}$ following $\mathrm{KCl}$ extraction (Mulvaney, 1996).

Urea fertilizer (46-0-0) was applied in a series of incremental $\mathrm{N}$ rates to create replicated, parallel $\mathrm{N}$ strips across a field (Fig. $2 \mathrm{~B}$ ). Nitrogen rates ranged from 0 to $112 \mathrm{~kg} \mathrm{ha}^{-1}$ in six increments at Simpson-1994 and four at Highwood-2001; 0 to $90 \mathrm{~kg} \mathrm{ha}^{-1}$ in five increments at Simpson-1995, Havre-2001, Malta-2001, and Malta-2002; and from 0 to $67 \mathrm{~kg} \mathrm{ha}^{-1}$ in four increments at Malta2003 and Malta-2004 (Table 1). Strip width varied with the size of the fertilizer applicator. Urea fertilizer was broadcast at Simpson and Highwood by means of a truck-mounted applicator with a $18.3-\mathrm{m}$ boom followed by seeding of wheat with either a disk- or hoe-type seeder. At the other sites, fertilizer was banded below the seed using an air seeder. At Havre, each N strip was established with two passes of a 3.1-m Concord air seeder. Strips at Malta were established with a single pass of a 6.1-m Concord air seeder.

Strips were cut using a combine harvester equipped with a GPS receiver and yield monitor (Model YM2000, AgLeader Inc.) set to read at 1-s intervals. At least 300 grain samples were collected by hand from the combine's grain bin filling auger. Samples were collected in either 20- or 30-s intervals as the combine traveled along a strip and were labeled with the Coordinated Universal Time of collection. After harvest, samples were cleaned of foreign material and analyzed for PC using a whole-grain near-infrared analyzer. Protein measurements were standardized to $120 \mathrm{~g} \mathrm{~kg}^{-1}$ (12\%) grain moisture content in accordance with market standards for HRSW. The position of each yield and protein observation was corrected by subtracting an 11-s difference between cutting the crop at the header and collecting the grain on the top of the clean grain elevator. Histograms were used to identify and delete erroneous values caused by sudden stoppage of the combine and by filling or emptying of grain as the combine entered or exited the field.

\section{Creation of Data Sets}

Soil test $\mathrm{N}$ measurements and expected yield goals were used to derive $\mathrm{N}$ recommendations based on fertility guidelines for HRSW (Jones and Jacobsen, 2001). Yield goals $\left(\mathrm{kg} \mathrm{ha}^{-1}\right)$ were based on farmer experience and were multiplied by $0.0467 \mathrm{~kg}$ $\mathrm{N} \mathrm{kg}^{-1}$ grain to calculate the $\mathrm{N}$ requirement $\left(\mathrm{kg} \mathrm{ha}^{-1}\right)$. Soil $\mathrm{NO}_{3}-\mathrm{N}$ measurements were subtracted from the $\mathrm{N}$ requirement to produce the $\mathrm{N}$ recommendations. Two experimental $\mathrm{N}$ management scenarios were evaluated:

1. Uniform $\mathrm{N}$ management with an expected yield goal of 2018 $\mathrm{kg} \mathrm{ha}^{-1}$. Soil test $\mathrm{N}$ was determined by averaging soil $\mathrm{NO}_{3}-\mathrm{N}$ values within a field.

2. Variable $\mathrm{N}$ management based on $\mathrm{MZ}$ with variable yield goals of 1682, 2018, 2354, and $2690 \mathrm{~kg} \mathrm{ha}^{-1}$ in low, moderate, moderately high, and high productivity zones. Soil test $\mathrm{N}$ was determined for each $\mathrm{MZ}$ by averaging soil $\mathrm{NO}_{3}-\mathrm{N}$ values within a $\mathrm{MZ}$ analogous to compositing samples into one for laboratory analysis.

Collecting 10 to 15 randomly distributed surface cores and six to eight subsoil cores is considered acceptable for representing the average nutrient status in 16.2-ha areas (Ferguson and Hergert, 2009). In this study, the sample number ranged from five in 2.9 ha (Simpson-1995) to 50 in 19 ha (Highwood-2001) (Table 2). Therefore, the zone sampling approach of this study was deemed appropriate.

Figure 2C shows the method of simulating uniform-rate or variable-rate treatments across a field. Fertilizer rates for UNM consisted of the $\mathrm{N}$ strips that corresponded with the $\mathrm{N}$ recommendation for the entire field. The VNM program consisted of the $\mathrm{N}$ strips that corresponded with the $\mathrm{N}$ recommendations for all MZs within the field. If uniform- and variable-rate treatments shared the same $\mathrm{N}$ strip within a $\mathrm{MZ}$, then the yield measurements within the $\mathrm{N}$ strip were randomly allocated to one group for UNM or one for VNM (Fig. 2C, see inset). At Simpson-1994 and Simpson-1995, each strip was wide enough to cut into two parallel, non-overlapping swaths, and so the observations in one swath could be allocated to one group and those of the second swath to the other. In all other trials, the strips were wide enough to accommodate only one combine swath. In that case, yield and protein observations in a data series were randomly assigned to either a variable group or a uniform group if both shared the same $\mathrm{N}$ rate within the same MZ.

Each data set was also analyzed using expected crop responses to applied $\mathrm{N}$, the costs of $\mathrm{N}$, and the expectations of harvest prices based on available information at planting. The $\mathrm{N}$ rate that 
optimized net dollar returns for UNM was predicted from a plot of net return vs. applied N. For VNM, the N rates that optimized net returns were predicted from plots of mean grain yield vs. applied $\mathrm{N}$ using the data within each MZ. Thus, only the yield observations of the $\mathrm{N}$ rates that were predicted to optimize grain net returns, either for the whole field or for each $\mathrm{MZ}$, were selected for analysis.

Each yield and protein record of a data series was classified by treatment strip number, replication, $\mathrm{N}$ fertilizer rate, and $\mathrm{MZ}$. The Proc Univariate of SAS (SAS Institute) was used to compute the mean, standard deviation, and minimum and maximum values for yield and gross return with respect to $\mathrm{N}$ rate, $\mathrm{N}$ rate within a $\mathrm{MZ}$, and variable and uniform $\mathrm{N}$ management. The average $\mathrm{PC}$ within an $\mathrm{N}$ strip of a $\mathrm{MZ}$ was used to establish the wheat price to be associated with the grain yield received from variable or uniform $\mathrm{N}$ management. Gross returns were computed on a US dollars per kilogram basis by multiplying the grain yield times the average Portland market price for Dark Northern Spring Wheat during the 11 yr (1994-2004). Prices paid to producers were obtained from the Montana Wheat and Barley Committee. Portland prices are reported in US dollars per bushel to the whole percentage of PC (Pacific Northwest Grain Market News, http://www.ams.usda.gov/mnreports/lswpnwgrain.pdf) but county elevators pay premiums to the nearest $0.25 \% \mathrm{PC}$, with premiums applied between $14\left(140 \mathrm{~g} \mathrm{~kg}^{-1}\right)$ and $16 \%$ and discounts between 12 and 14\%. Protein premiums and discounts are rounded down to the nearest $0.25 \%$ (i.e., $142.4 \mathrm{~g} \mathrm{~kg}^{-1}$ protein is priced at the $140 \mathrm{~g} \mathrm{~kg}^{-1}$ price), as is common in this market. Thus, protein values were rounded down to the nearest $0.25 \%$ to establish the price for this wheat.

\section{Statistical Analyses}

The irregularly spaced yield data were extracted to the cells of a regular square grid using the Geoprocessing Wizard extension to ArcView 3.2 as needed for lagged autoregressive response (AR) modeling (Upton and Fingleton, 1985). The SAS code of Griffith (1993) was used to estimate an AR model having the form

$$
Y=\rho \mathbf{C} Y+\beta_{0}+\varepsilon
$$

where $Y$ is grain yield, $\rho$ is the spatial autocorrelation parameter, $\mathbf{C}$ is a spatial weights matrix, $\beta$ is a coefficient to be

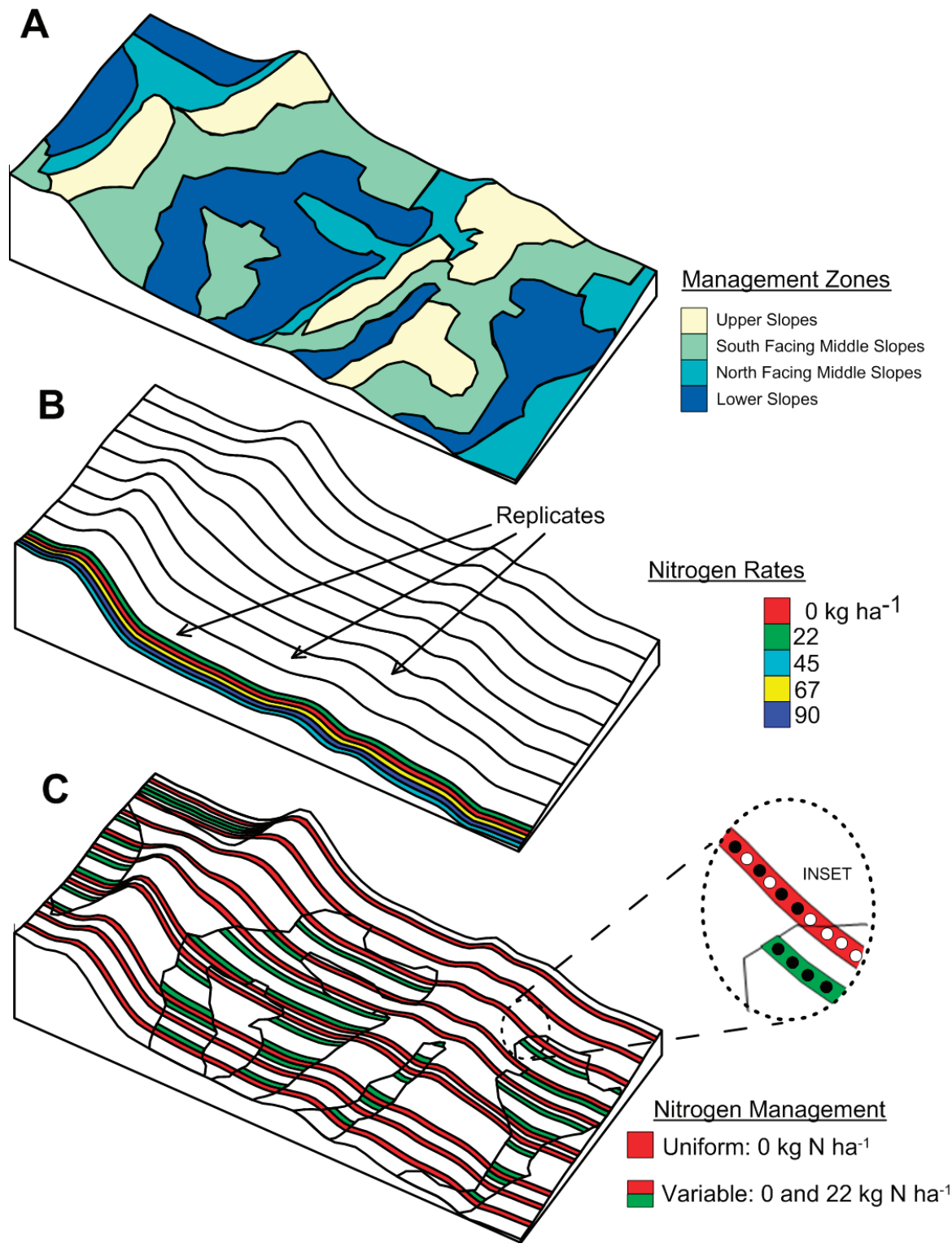

Fig. 2. Block diagrams of the Havre-200I site with overlays of $(A)$ four management zones that were computed using terrain modeling procedures, (B) $N$ trial design with sets of $\mathrm{N}$ rate organized into replicates that are oriented along the length of the field against a ridge and valley pattern, and (C) $\mathrm{N}$ management treatments created for comparison of variable-rate $\left(0\right.$ and $22 \mathrm{~kg} \mathrm{~N} \mathrm{ha}^{-1}$, green colored strips in lower slope positions and red colored strips in remaining management zones) and uniformrate $\left(0 \mathrm{~kg} \mathrm{~N} \mathrm{ha}^{-1}\right.$, red colored strips across field) fertilizer application. Black dots within the green-colored strip in the lower slopes are yield data points allocated to a data set for variable $\mathrm{N}$ management (inset). White dots within the red-colored strip in the lower slopes are yield points that are allocated to a data set for uniform management. Elsewhere, black and white dots appearing together within the same red-colored $\mathrm{N}$ strip shared the same $\mathrm{N}$ rate and thus are randomly allocated within the strip to either a data set for variable management or one for uniform management. 
estimated, and $\varepsilon$ are randomly distributed errors. This method transforms a variable containing spatial autocorrelation into one free of autocorrelation by partitioning the variance of the original georeferenced variable $(Y)$ into variance that is attributable to autocorrelation and variance that is attributable to nonspatial effects (Griffith and Peres-Neto, 2006). The nonspatial variate that is adjusted for autocorrelation $\left(Y_{\text {adj }}\right)$ is calculated by subtracting the variate containing the autocorrelation $(\rho \mathbf{C} Y)$ from the original variate $(Y)$ :

$$
Y_{\text {adj }}=Y-\left(\rho \mathbf{C} Y-\rho \beta_{0}\right)
$$

Ordinary statistical methods can then be used to test for associations between dependent and independent variables.

After this transformation, analysis of variance (ANOVA) was conducted using Proc GLM (SAS Institute) to determine if the effect of $\mathrm{N}$ on yield differed within the MZs of each field. The ANOVA model was

Table 2. Yield goal, soil sample number (n), soil test $\mathrm{NO}_{3}-\mathrm{N}, \mathrm{N}$ recommendation, and $\mathrm{N}$ applied in each field by site-year and its management zones.

\begin{tabular}{|c|c|c|c|c|c|}
\hline Management zone & Yield Goal & $n$ & Soil $\mathrm{NO}_{3}-\mathrm{N}$ & $\mathrm{N}$ recommendation & $\mathrm{N}$ applied \\
\hline & $\mathrm{kg} \mathrm{ha}^{-1}$ & & 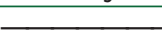 & $\mathrm{kg} \mathrm{ha}^{-1}$ & \\
\hline \multicolumn{6}{|l|}{ Simpson-1994 } \\
\hline Whole field & 2018 & 60 & 70 & 24 & 22 \\
\hline Upper slopes & 1682 & 11 & 61 & 18 & 22 \\
\hline Middle north & 2018 & 13 & 65 & 29 & 22 \\
\hline Middle south & 2354 & 26 & 70 & 40 & 45 \\
\hline Lower slopes & 2690 & 10 & 68 & 58 & 67 \\
\hline \multicolumn{6}{|l|}{ Simpson-1995 } \\
\hline Whole field & 2018 & 39 & 52 & 42 & 45 \\
\hline Upper slopes & 1682 & 8 & 49 & 30 & 22 \\
\hline Middle north & 2018 & 5 & 65 & 29 & 22 \\
\hline Middle south & 2354 & 16 & 49 & 61 & 67 \\
\hline Lower slopes & 2690 & 10 & 53 & 73 & 67 \\
\hline \multicolumn{6}{|l|}{ Highwood-200I } \\
\hline Whole field & 2018 & 90 & 17 & 79 & 75 \\
\hline Upper slopes & 1682 & 19 & 16 & 77 & 75 \\
\hline Middle north & 2018 & 50 & 17 & 77 & 75 \\
\hline Middle south & 2354 & 5 & 16 & 93 & 112 \\
\hline Lower slopes & 2690 & 16 & 18 & 108 & 112 \\
\hline \multicolumn{6}{|l|}{ Havre-200I } \\
\hline Whole field & 2018 & 76 & 99 & 0 & 0 \\
\hline Upper slopes & 1682 & 15 & 90 & 0 & 0 \\
\hline Middle north & 2018 & 11 & 91 & 3 & 0 \\
\hline Middle south & 2354 & 30 & 100 & 10 & 0 \\
\hline Lower slopes & 2690 & 20 & 100 & 26 & 22 \\
\hline \multicolumn{6}{|l|}{ Malta-200I } \\
\hline Whole field & 2018 & 68 & 75 & 19 & 22 \\
\hline Upper slopes & 1682 & 19 & 73 & 6 & 0 \\
\hline Middle north & 2018 & 25 & 84 & 10 & 0 \\
\hline Middle south & 2354 & 15 & 62 & 48 & 45 \\
\hline Lower slopes & 2690 & 9 & 84 & 42 & 45 \\
\hline \multicolumn{6}{|l|}{ Malta-2002 } \\
\hline Whole field & 2018 & $|4|$ & 76 & 18 & 22 \\
\hline Upper slopes & 1682 & 28 & 61 & 18 & 22 \\
\hline Middle north & 2018 & 38 & 74 & 20 & 22 \\
\hline Middle south & 2354 & 42 & 70 & 40 & 45 \\
\hline Lower slopes & 2690 & 33 & 103 & 23 & 22 \\
\hline \multicolumn{6}{|l|}{ Malta-2003 } \\
\hline Whole field & 2018 & 38 & 72 & 22 & 22 \\
\hline Upper slopes & 1682 & 7 & 45 & 34 & 45 \\
\hline Middle north & 2018 & 10 & 65 & 29 & 22 \\
\hline Middle south & 2354 & 15 & 66 & 44 & 45 \\
\hline Lower slopes & 2690 & 6 & 126 & 0 & 0 \\
\hline \multicolumn{6}{|l|}{ Malta-2004 } \\
\hline Whole field & 2018 & 77 & 66 & 28 & 22 \\
\hline Upper slopes & 1682 & 21 & 47 & 32 & 22 \\
\hline Middle north & 2018 & 21 & 59 & 35 & 45 \\
\hline Middle south & 2354 & 24 & 71 & 39 & 45 \\
\hline Lower slopes & 2690 & 114 & 91 & 35 & 45 \\
\hline
\end{tabular}


Table 3. Cost of materials and supplies used for uniform-rate and variable-rate $\mathrm{N}$ management.

\begin{tabular}{|c|c|c|c|c|c|}
\hline Operation & Material or service & Unit & Price per unit & Units & Cost \\
\hline & & & US\$ & no. $\mathrm{ha}^{-1}$ & US\$ ha-I \\
\hline Soil sampling & custom service & field & 165 & - & $4.15-11.00$ \\
\hline Management zone delineation & custom service & ha & 1.76 & 1.00 & 1.76 \\
\hline Fertilization & $\mathrm{N}$ & $\mathrm{kg}$ & 0.87 & $0-112$ & 0-97.4 \\
\hline Variable-rate $\mathrm{N}$ application & rate controller & - & 14,000 & - & 4.45 \\
\hline Harvest & yield monitor & - & 5,295 & - & 1.69 \\
\hline Harvest & GPS receiver & - & 895 & - & 0.28 \\
\hline Harvest & mapping software & - & 750 & - & 0.35 \\
\hline
\end{tabular}

Table 4. Example partial budget by change in grain yield, grain value, and costs between uniform-rate and variable-rate $\mathrm{N}$ management (VNM) for the Simpson-1994 site by management zone (MZ).

\begin{tabular}{|c|c|c|c|}
\hline \multirow[t]{2}{*}{ Parameter } & \multirow{2}{*}{$\begin{array}{c}\text { Rate } \\
\mathrm{kg} \mathrm{ha}^{-1}\end{array}$} & \multicolumn{2}{|c|}{ Cost } \\
\hline & & US\$ $\mathrm{kg}^{-1}$ & US\$ ha-1 \\
\hline \multicolumn{4}{|l|}{ Upper slopes (MZ I), 22 kg N ha ${ }^{-1}$} \\
\hline Change in grain yield $\dagger$ & 0 & 0.1562 & 0.00 \\
\hline Change in value of grain $\ddagger$ & 2218 & 0.00 & 0.00 \\
\hline Total avg. gross returns & & & 0.00 \\
\hline Added VNM costs & & & 8.53 \\
\hline Change in $\mathrm{N}$ costs & 0 & 0.8747 & 0.00 \\
\hline Change in soil sampling costs & & & 4.15 \\
\hline Total avg. costs & & & 12.68 \\
\hline Net return & & & -12.68 \\
\hline \multicolumn{4}{|l|}{ North-facing middle slopes (MZ 2), $22 \mathrm{~kg} \mathrm{~N} \mathrm{ha}{ }^{-1}$} \\
\hline Change in grain yield & 0 & 0.1765 & 0.00 \\
\hline Change in value of grain & 2398 & 0.0 & 0.00 \\
\hline Total avg. gross returns & & & 0.00 \\
\hline Added VNM costs & & & 8.53 \\
\hline Change in $\mathrm{N}$ costs & 0 & 0.8747 & 0.00 \\
\hline Change in soil sampling costs & & & 4.15 \\
\hline Total avg. costs & & & 12.68 \\
\hline Net return & & & -12.68 \\
\hline \multicolumn{4}{|l|}{ South-facing middle slopes (MZ 3), $45 \mathrm{~kg} \mathrm{~N} \mathrm{ha}^{-1}$} \\
\hline Change in grain yield & 169 & 0.1765 & 29.82 \\
\hline Change in value of grain & 2512 & 0.0203 & 50.99 \\
\hline Total avg. gross returns & & & 80.81 \\
\hline Added VNM costs & & & 8.53 \\
\hline Change in $\mathrm{N}$ costs & 23 & 0.8747 & 20.12 \\
\hline Change in soil sampling costs & & & 4.15 \\
\hline Total avg. costs & & & 32.80 \\
\hline Net return & & & 48.01 \\
\hline \multicolumn{4}{|l|}{ Lower slopes (MZ 4), $67 \mathrm{~kg} \mathrm{~N} \mathrm{ha}^{-1}$} \\
\hline Change in grain yield & -38 & 0.1811 & -6.88 \\
\hline Change in value of grain & 2700 & 0.0185 & 49.95 \\
\hline Total avg. gross returns & & & 43.07 \\
\hline Added VNM costs & & & 8.53 \\
\hline Change in $\mathrm{N}$ costs & 45 & 0.8747 & 39.36 \\
\hline Change in soil sampling costs & & & 4.15 \\
\hline Total avg. costs & & & 52.04 \\
\hline Net return & & & -8.97 \\
\hline $\begin{array}{l}\text { Net return to variable-rate } N \text { management } \\
(-U S \$ 12.68 \times 0.19)+(-U S \$ 12.68 \times 0.21)+\end{array}$ & $0.17)$ & & 14.05 \\
\hline Added EQIP payment§ & & & 4.77 \\
\hline Added yield observation payment§ & & & 1.59 \\
\hline Total EQIP payments & & & 6.36 \\
\hline Net return including EQIP payments & & & 20.41 \\
\hline
\end{tabular}

$\dagger$ The change in grain yield in each management zone over the actual uniform $\mathrm{N}$ rate.

$\ddagger$ Change in value of grain is the difference in price determined by protein measurements between each management zone and the actual uniform $\mathrm{N}$ rate.

$\S$ Environmental Quality Incentives Program (EQIP) payment applied to 202 ha or about 18.4\% of typical II00-ha northern Montana farm. 


$$
\begin{aligned}
Y_{\text {adj }}= & \beta_{0}+\beta_{1} \mathrm{AN}+\beta_{2} R+\beta_{3} \mathrm{MZ}+ \\
& \beta_{4}(\mathrm{AN} \times \mathrm{MZ})+\beta_{5}(\mathrm{AN} \times R \times \mathrm{MZ})+\varepsilon
\end{aligned}
$$

where $Y_{\text {adj }}$ is spatially adjusted grain yield, AN is applied $\mathrm{N}, R$ is the replicate, $\mathrm{MZ}$ is the management zone, $\beta$ are parameters, and $\varepsilon$ is an error term. Regression terms were evaluated for significance using a partial $F$ test (Type III sums of squares) with AN $\times R \times$ $\mathrm{MZ}$ used as the error term. Average wheat yields and net returns from VNM and UNM could not be statistically compared because the same $\mathrm{N}$ strip within certain MZs had been used twice to compute these returns.

\section{Partial Budget Analysis}

Economic benefits from VNM were determined using partial budget analysis, which focuses on only those cost and revenue items that change because of the adoption of a new practice. Changes in revenue from adopting VNM resulted from changes in the yield and value of grain. Changes in costs resulted from changes associated with soil sampling, MZ delineation, fertilizer, variable-rate control equipment, and yield mapping equipment and software (Table 3). Partial budgets were constructed for all eight sites by MZ . Total mean net return for a field was the sum of the net returns from each MZ weighted by the area of each MZ. Table 4 illustrates an example of a partial budget by cost and revenue item for the Simpson-1994 site.

Variable costs associated with VNM included soil sampling, zone delineation, fertilizer, hardware, and software. Although combines can be purchased with yield monitors and air seeders with variable-rate hardware installed, it was assumed that a producer does not own pre-installed equipment. Fixed ownership costs associated with other machinery were ignored because they do not change with $\mathrm{N}$ management strategy. All variable costs are based on an average size farm (about $1100 \mathrm{ha}$ ) in the north-central region of Montana (National Agricultural Statistics Service, 2009). Equipment costs were for acquiring a yield monitor, GPS receiver, and hardware and software for adapting an air seeder for variable-rate application.

Environmental Quality Incentives Program (EQIP) payments from the USDA-NRCS offset the costs of adopting new technologies for VNM. To participate, producers must delineate at least three MZs based on soil electrical conductivity maps, sequential yield maps, aerial imagery, grid soil sampling, or some other suitable method and apply fertilizer to the zones using a variablerate applicator. In Montana, EQIP pays US $\$ 25.93 \mathrm{ha}^{-1}$ with a maximum benefit of US\$5250 or enough money to use VNM on $202 \mathrm{ha}$. A yield mapping payment of US $\$ 18.52 \mathrm{ha}^{-1}$ is included for the first year and US $\$ 3.70 \mathrm{ha}^{-1}$ for the remaining $2 \mathrm{yr}$ of a $3-\mathrm{yr}$ contract. This benefit was averaged across the $3 \mathrm{yr}\left(\mathrm{US} \$ 8.64 \mathrm{ha}^{-1}\right)$. A total EQIP payment of US $\$ 34.57 \mathrm{ha}^{-1}$ for 202 ha was spread across a total of 1100 ha, which brought it to US $\$ 6.35 \mathrm{ha}^{-1}$.

An initial investment in technology, information, and software is required to participate in VNM. Therefore, a $10 \%$ opportunity cost was considered for each item of the investment. Opportunity costs represent the next best alternative use for a producer's investment (Lowenberg-DeBoer, 2000). For instance, if a farmer could have reduced interest expenses by reducing debt rather than purchasing equipment, then the interest rate on the debt becomes the opportunity cost for investing in VNM. Information, technology, and software costs were treated as durable goods because they are capital assets. These costs were spread across an assumed $4 \mathrm{yr}$ of useful life. After the average annual cost of capital assets was established, the cost was divided by the number of productive hectares on a farm during a given year to calculate the cost in US dollars per hectare.

Fertilizer costs were calculated by multiplying the unit cost of $\mathrm{N}$ in urea by the application rate. Fertilizer costs were based on the average 2009 spring fertilizer price of US $\$ 365$ ton $^{-1}$ of urea, or US $\$ 0.87 \mathrm{~kg}^{-1}$ of N. Typically, soil fertility information is gathered using a directed sampling approach whereby the soil samples are taken at a limited number of locations and bulked to form one composite sample per MZ (Franzen, 2008). Local fertilizer dealers charged US $\$ 55$ per field for soil sampling and laboratory analysis of a single composite sample. Added costs for soil sampling under VNM would entail one composite soil sample per MZ instead of one for the entire field. Four MZs were involved in this study and so the total cost difference was US\$165 per field $(3 \times 55=$ 165). Therefore, the cost difference per hectare for each field was US $\$ 165$ divided by the total hectares of the field.

Producers often use the services of companies to build variablerate control maps for their farms. Information costs were quoted by LandMapper Environmental Solutions, Inc., at US $\$ 1300$ per section $(640$ acres $=259 \mathrm{ha})$ for acquiring a 30 -m DEM from the USGS and using the LandMapR software to divide the DEM into upper, middle, and lower slopes. This information was treated as a durable asset with a 4 -yr useful life and subject to a $10 \%$ opportunity cost. The opportunity cost equaled $10 \%$ of US $\$ 1300$, or US $\$ 130$, and the annual cost was US $\$ 1300 / 4$, or US $\$ 325$, which brought the total annual cost to US\$455 $(130+325=455)$. The cost per hectare was US $\$ 455$ divided by 259 ha or US $\$ 1.76 \mathrm{ha}^{-1}$.

Based on quotations from a local dealer, the cost of a yield monitor was US\$5295, and a suitable GPS receiver used with this monitor was US\$895. A producer must also purchase the variablerate control system for their seed drill. A local vendor estimated this cost at $\leq$ US $\$ 14,000$. This technology was treated as a 4-yr durable asset with a $10 \%$ opportunity cost spread across 1100 ha of the farm, which meant that the annual cost of the system was US $\$ 4900(1400+3500=4900)$ or US\$ $\$ .45 \mathrm{ha}^{-1}(4900 / 1100=$ 4.45). Equipment costs of the yield monitor and GPS receiver were computed in the same way. In addition, mapping software is needed to satisfy EQIP requirements of producing as-applied $\mathrm{N}$ maps and yield maps. The SMS software package, priced at US\$750 from AgLeader Technology, Inc., satisfies this requirement. A maintenance fee of US $\$ 120$ is charged for each year the producer uses the software. Therefore, the total annual cost of the software across its 4 -yr useful life is US $\$ 385$ or US $\$ 0.35 \mathrm{ha}^{-1}$.

\section{RESULTS AND DISCUSSION}

Growing conditions were unusually dry in 2001 at Highwood and Havre, with above-normal July temperatures during grain filling (Table 5). In contrast, growing season rainfall was above the long-term average at Simpson-1995 in June and July so wheat experienced little drought stress. Precipitation was somewhat below average (87-89\%) at Malta in 2001, 2002, and 2004, but July rainfall was above average during grain filling in 2001 and 2004. Seasonal rainfall was near normal at the Simpson-1995 and Malta-2003 sites, but July was dry with above-average temperatures during grain filling. 
Table 5. Monthly precipitation (Precip.), average temperature (Temp.), and the fraction of long-term precipitation recorded at the nearest weather stations for eight sites in northern Montana.

\begin{tabular}{|c|c|c|c|c|c|c|}
\hline Site-year $†$ & Variable & April & May & June & July & $\begin{array}{l}\text { Fraction of } \\
\text { long-term }\end{array}$ \\
\hline & & & & & & $\%$ \\
\hline \multirow[t]{2}{*}{ Simpson-1994 } & Precip., mm & $24.4(19.6) \ddagger$ & $33.5(41.4)$ & $74.9(60.2)$ & I I.9 (33.8) & 93 \\
\hline & Temp., ${ }^{\circ} \mathrm{C}$ & $7.4(6.0)$ & $13.9(12.1)$ & $16.9(16.3)$ & $20.7(20.3)$ & - \\
\hline \multirow[t]{2}{*}{ Simpson-1995 } & Precip., mm & $22.4(19.6)$ & $37.8(41.4)$ & | 48.6 (60.2) & $58.7(33.8)$ & 173 \\
\hline & Temp., ${ }^{\circ} \mathrm{C}$ & $4.8(6.0)$ & $11.6(12.1)$ & $16.6(16.3)$ & I $8.6(20.3)$ & - \\
\hline \multirow[t]{2}{*}{ Highwood-200I } & Precip., mm & $22.1(35.6)$ & $9.9(75.4)$ & 84.1 (90.2) & $72.6(38.6)$ & 79 \\
\hline & Temp., ${ }^{\circ} \mathrm{C}$ & - & - & - & - & - \\
\hline \multirow[t]{2}{*}{ Havre-200I } & Precip., mm & $24.9(25.9)$ & $10.9(45.7)$ & $35.6(65.3)$ & $50.8(36.6)$ & 70 \\
\hline & Temp., ${ }^{\circ} \mathrm{C}$ & $5.8(6.6)$ & 14.6 (12.6) & $17.2(16.9)$ & $22.4(2 I .1)$ & - \\
\hline \multirow[t]{2}{*}{ Malta-200I } & Precip., mm & 18.5 (24.9) & $21.6(58.7)$ & $73.4(66.0)$ & $52.8(41.9)$ & 87 \\
\hline & Temp., ${ }^{\circ} \mathrm{C}$ & $6.2(7.3)$ & 14.1 (13.1) & 16.6 (17.9) & $22.2(21.3)$ & - \\
\hline \multirow[t]{2}{*}{ Malta-2002 } & Precip., mm & $7.9(24.9)$ & I 8.8 (58.7) & $108.7(66.0)$ & $35.3(41.9)$ & 89 \\
\hline & Temp., ${ }^{\circ} \mathrm{C}$ & $4.0(7.3)$ & $10.7(13.1)$ & 18.6 (17.9) & $22.7(2 \mid .3)$ & - \\
\hline \multirow[t]{2}{*}{ Malta-2003 } & Precip., mm & $43.4(24.9)$ & $69.9(58.7)$ & $54.6(66.0)$ & 29.7 (41.9) & 103 \\
\hline & Temp., ${ }^{\circ} \mathrm{C}$ & 8.7 (7.3) & $12.1(13.1)$ & $16.6(17.9)$ & $22.8(2 \mid .3)$ & - \\
\hline \multirow[t]{2}{*}{ Malta-2004 } & Precip., mm & $10.2(24.9)$ & 86.1 (58.7) & $25.1(66.0)$ & $46.0(41.9)$ & 87 \\
\hline & Temp., ${ }^{\circ} \mathrm{C}$ & $8.8(7.3)$ & $10.3(13.1)$ & | 4.8 (I7.9) & $20.4(2 \mid .3)$ & - \\
\hline
\end{tabular}

† Site and nearest NOAA cooperative weather station (with period of record in parentheses): Simpson, Simpson 6N (I93I-20I3); Malta, Malta 7E (I972-20I3); Havre, Fort Assiniboine (1917-2013); Highwood, Highwood 7 NE (1948-2013). Temperature and precipitation data summaries for NOAA cooperative stations available online at http://www.wrcc.dri.edu/climatedata/climsum/.

$\ddagger$ Long-term averages in parentheses.

\section{Weighted Mean Nitrogen Rates, Grain Yields, and Grain Protein}

The $\mathrm{N}$ applied for both management strategies ranged from 0 to $112 \mathrm{~kg} \mathrm{~N} \mathrm{ha}^{-1}$ across the eight sites (Table 1). The areal weighted rate of $\mathrm{N}$ fell between 7 and $84 \mathrm{~kg} \mathrm{ha}^{-1}$ for VNM and 0 and $75 \mathrm{~kg} \mathrm{~N} \mathrm{ha}^{-1}$ for UNM (Table 6). The average rate of $\mathrm{N}$ applied was lower under UNM at seven of the eight field sites. Compared with UNM, the $\mathrm{N}$ applied from VNM was 50\% less at Malta2001 but was up to $82 \%$ more on the remaining sites. Therefore, VNM based on zone sampling and university $\mathrm{N}$ recommendations did not reduce total fertilizer usage.

Weighted mean grain yield across all sites ranged from 838 to $3422 \mathrm{~kg} \mathrm{ha}^{-1}$ (Table 6), probably in response to differences in plant-available water. In general, field-average grain yields increased with growing season rainfall (April-July) in the order of Highwood (73\% of long term), Havre (71\%), Malta-2003 (105\%), Malta-2001 (89\%), Malta-2002 (89\%), Simpson-1994 (100\%), Malta-2004 (89\%), and Simpson-1995 (180\%). The 2003 Malta yield departed from the trend because of heat stress during grain filling. Mean grain PC varied inversely to yield, from 178 to $104 \mathrm{~g} \mathrm{~kg}^{-1}$. There was little practical difference in weighted mean grain yield and PC between the two $\mathrm{N}$ management strategies.

\section{Crop Response to Applied Nitrogen within Management Zones}

Grain yield was similar for UNM and VNM programs within the four MZs at each of the eight field locations. Yield differences never exceeded $223 \mathrm{~kg} \mathrm{ha}^{-1}$ and averaged only $18 \mathrm{~kg} \mathrm{ha}^{-1}$, indicating that the agronomic performance of the two management strategies was similar (Table 6). Despite having the greatest long-term precipitation, yields at Highwood were least due to abnormally dry conditions that were further compounded by continuous cropping. In contrast, summer fallow at the other sites probably improved the availability of water and $\mathrm{N}$, and increased the yield potential and nutrient requirement. In 2001, which was a dry year, UNM resulted in more $\mathrm{N}$ in south-facing middle slopes and lower slopes than UNM at Highwood, and more $\mathrm{N}$ in lower slopes than UNM at Havre. Overfertilizing with $N$ reduces grain yield by stimulating increased vegetative growth that in turn depletes soil moisture before flowering and grain filling (Campbell et al., 1977). Therefore, the amount of $\mathrm{N}$ applied coupled with drought probably reduced yield and increased protein in these MZs.

Under above-average precipitation, such as at Simpson-1995, mean grain yield was greatest and $\mathrm{PC}$ was least. In water-limited environments, an inverse yield-protein relationship is attributed to dilution of a fixed amount of grain $\mathrm{N}$ by a much larger biomass with increases in plant-available water (Terman et al., 1969). At this location, upper and south-facing middle slopes under VNM received $50 \%$ less $\mathrm{N}$ than those under $\mathrm{UNM}$ and had decreased $\mathrm{PC}$ and yield, which would be expected if $\mathrm{N}$ was insufficient. In contrast, $\mathrm{VNM}$, which applied $33 \%$ more $\mathrm{N}$ on lower slopes, increased yield and PC in this MZ. An exception occurred for north-facing middle slopes, where the yield change was negative, possibly due to overfertilization.

Long-term growing season precipitation was near normal at the Simpson and Malta sites during 1994, 2001, 2002, 2003, and 2004. Grain yield and PC was increased in south-facing middle slopes at Simpson-1994, Malta-2001, Malta-2002, and Malta2003 and lower slopes at Malta-2001 and Malta-2004, where the variable $\mathrm{N}$ rate exceeded that of the uniform $\mathrm{N}$ rate. In contrast, grain yield and protein tended to decrease on upper and northfacing middle slopes at Malta-2001, where the $\mathrm{N}$ applied in the variable treatment was less than that in the uniform treatment, which suggests that $\mathrm{N}$ recommendations for $\mathrm{VNM}$ at this site were inaccurate.

For VNM, wheat yields increased from upper to lower slopes at Simpson-1994, Simpson-1995, and Malta-2003 (Table 7), where precipitation was near to above normal. In contrast, in 2001, 
Table 6. Uniform $\mathrm{N}$ rate, variable $\mathrm{N}$ rate, change $(\Delta)$ in grain yield, change in grain protein, and area percentage by management zone, along with weighted mean $\mathrm{N}$ rate, weighted mean grain yield, and weighted grain protein at eight sites in northern Montana.

\begin{tabular}{|c|c|c|c|c|c|c|c|c|}
\hline \multirow[b]{2}{*}{ Parameter } & \multicolumn{2}{|c|}{ Simpson } & \multirow{2}{*}{$\frac{\text { Highwood }}{2001}$} & \multirow{2}{*}{$\begin{array}{l}\text { Havre } \\
2001\end{array}$} & \multicolumn{4}{|c|}{ Malta } \\
\hline & 1994 & 1995 & & & 2001 & 2002 & 2003 & 2004 \\
\hline \multicolumn{9}{|c|}{ Upper slopes } \\
\hline Uniform $\mathrm{N}$ rate, $\mathrm{kg} \mathrm{ha}{ }^{-1}$ & 22 & 45 & 75 & 0 & 22 & 22 & 22 & 22 \\
\hline Variable $\mathrm{N}$ rate, $\mathrm{kg} \mathrm{ha}^{-1}$ & 22 & 22 & 75 & 0 & 0 & 22 & 45 & 22 \\
\hline$\Delta$ Yield, $\mathrm{kg} \mathrm{ha}{ }^{-1} \dagger$ & 0 & -223 & 0 & 0 & -126 & 0 & -91 & 0 \\
\hline$\Delta$ Protein, $\mathrm{g} \mathrm{kg}^{-1}$ & 0 & -2 & 0 & 0 & -7 & 0 & 9 & 0 \\
\hline Area, $\%$ & 19 & 20 & 21 & 18 & 27 & 21 & 18 & 27 \\
\hline \multicolumn{9}{|c|}{ South-facing middle slopes } \\
\hline Uniform $\mathrm{N}$ rate, $\mathrm{kg} \mathrm{ha} \mathrm{h}^{-\mathrm{I}}$ & 22 & 45 & 75 & 0 & 22 & 22 & 22 & 22 \\
\hline Variable $\mathrm{N}$ rate, $\mathrm{kg} \mathrm{ha}^{-1}$ & 45 & 22 & 112 & 0 & 45 & 45 & 45 & 45 \\
\hline$\Delta$ Yield, $\mathrm{kg} \mathrm{ha}^{-\mathrm{l}}$ & 169 & -124 & -68 & 0 & 12 & 46 & 52 & -13 \\
\hline$\Delta$ Protein, $\mathrm{g} \mathrm{kg}^{-1}$ & 25 & -9 & 5 & 0 & 5 & 15 & 6 & 7 \\
\hline Area, $\%$ & 21 & 14 & 55 & 32 & 36 & 26 & 26 & 26 \\
\hline \multicolumn{9}{|c|}{ North-facing middle slopes } \\
\hline Uniform $\mathrm{N}$ rate, $\mathrm{kg} \mathrm{ha} \mathrm{ha}^{-1}$ & 22 & 45 & 75 & 0 & 22 & 22 & 22 & 22 \\
\hline Variable $\mathrm{N}$ rate, $\mathrm{kg} \mathrm{ha}^{-1}$ & 22 & 67 & 75 & 0 & 0 & 22 & 22 & 45 \\
\hline$\Delta$ Yield, $\mathrm{kg} \mathrm{ha}^{-\mathrm{l}}$ & 0 & -93 & 0 & 0 & -58 & 0 & 0 & 125 \\
\hline$\Delta$ Protein, $\mathrm{g} \mathrm{kg}^{-1}$ & 0 & 7 & 0 & 0 & -6 & 0 & 0 & 4 \\
\hline Area, \% & 43 & 40 & 7 & 16 & 22 & 29 & 39 & 31 \\
\hline \multicolumn{9}{|c|}{ Lower slopes } \\
\hline Uniform $\mathrm{N}$ rate, $\mathrm{kg} \mathrm{ha}{ }^{-1}$ & 22 & 45 & 75 & 0 & 22 & 22 & 22 & 22 \\
\hline Variable $\mathrm{N}$ rate, $\mathrm{kg} \mathrm{ha}^{-1}$ & 67 & 67 & 112 & 22 & 45 & 22 & 0 & 45 \\
\hline$\Delta$ Yield, $_{\mathrm{kg} \mathrm{ha}} \mathrm{h}^{-1}$ & -38 & 199 & -5 & -12 & 168 & 0 & 113 & 84 \\
\hline$\Delta$ Protein, $\mathrm{g} \mathrm{kg}^{-1}$ & 23 & 17 & 4 & 6 & 4 & 0 & -6 & 6 \\
\hline Area, $\%$ & 17 & 26 & 17 & 34 & 15 & 24 & 17 & 16 \\
\hline \multicolumn{9}{|c|}{$\underline{\text { Weighted mean } \mathrm{N} \text { rate } \neq, \mathrm{kg} \mathrm{ha}^{-1}}$} \\
\hline Uniform & 22 & 45 & 75 & 0 & 22 & 22 & 22 & 22 \\
\hline Variable & 40 & 52 & 84 & 7 & II & 29 & 31 & 39 \\
\hline \multicolumn{9}{|c|}{ Weighted mean grain yield, $\mathrm{kg} \mathrm{ha}^{-1}$} \\
\hline Uniform & 2354 & 3383 & 848 & 1061 & 2473 & 2057 & 1512 & 2718 \\
\hline Variable & 2327 & 3422 & 838 & 1035 & 2402 & 2050 & $|56|$ & 2757 \\
\hline \multicolumn{9}{|c|}{ Weighted mean grain protein, $\mathrm{g} \mathrm{kg}^{-1}$} \\
\hline Uniform & 145 & 104 & 164 & 169 & $|4|$ & 149 & 176 & 152 \\
\hline Variable & 142 & 112 & 165 & 166 & 142 & 154 & 178 & 152 \\
\hline
\end{tabular}

$\dagger$ Change in grain yield or grain protein when changing from uniform to variable $\mathrm{N}$ management.

$\ddagger$ Mean net return weighted by percentage of management zone area.

which was the driest year, yields in upper slope positions at Havre and Malta were highest. Based on our experience, in dry years, upper slopes may yield best because coarser textured soils in these positions have more infiltration and release of the water that fell from short-duration, high-intensity thunderstorms than finer textured soils on lower slopes. At other locations, little difference in yield was observed between MZs, probably due to extreme dryness. The lack of a consistent relationship between slope position and grain yield indicates how weather can influence yield response to $\mathrm{N}$ application and makes it difficult to establish yield goals and use slope position to accurately construct MZs.

The autocorrelation parameter $(\rho)$ accounted for a large proportion of variance in grain yield and was highly significant $(P>0.05)$ in each site-year (Table 7). Accordingly, grain yield significantly differed among MZs in most fields by ordinary ANOVA but only in a few fields by AR-based ANOVA. Maximum grain yield with $\mathrm{N}$ level ranged from 692 to $3938 \mathrm{~kg} \mathrm{ha}^{-1}$ across all site-years. Grain yield was increased by $\mathrm{N}$ fertilization in four out of eight site-years that received normal to above-normal precipitation. However, the effect of the $\mathrm{N} \times \mathrm{MZ}$ interaction was insignificant, indicating that the response of grain yield to $\mathrm{N}$ did not vary significantly by MZ. One would not expect VNM to perform better than $\mathrm{UNM}$ if changing the $\mathrm{N}$ rate (increasing $\mathrm{N}$ on lower slopes or decreasing $\mathrm{N}$ on upper slopes) produced little yield response. An exception is Havre-2001, where the AR-based ANOVA showed a significant $\mathrm{N} \times \mathrm{MZ}$ interaction.

\section{Net Returns}

A decision to practice VNM would be based on the added revenue associated with an advantage in grain quality and/or yield minus the added cost of new equipment and soil sampling and net increases or decreases in $\mathrm{N}$ use. Table 8 shows partial budget analyses based on the grain quality and yield data at the eight sites and market prices at Portland, OR. Greater annual fixed costs for implementing variable-rate $\mathrm{N}$ application were associated with the purchase of a yield monitor, GPS receiver, and variable-rate control system for a grain drill. Greater variable costs include additional soil testing costs based on four MZs and the size of a field. 
Table 7. Effect of $\mathrm{N}$ rate and management zone (MZ) on spring wheat yield for eight site-years in northern Montana.

\begin{tabular}{|c|c|c|c|c|c|c|c|c|c|}
\hline Management zone & $\mathrm{N}$ rate & $\begin{array}{l}\text { Simpson- } \\
1994\end{array}$ & $\begin{array}{l}\text { Simpson- } \\
1995\end{array}$ & $\begin{array}{l}\text { Havre- } \\
2001\end{array}$ & $\begin{array}{l}\text { Highwood- } \\
2001\end{array}$ & $\begin{array}{l}\text { Malta- } \\
2001\end{array}$ & $\begin{array}{l}\text { Malta- } \\
2002\end{array}$ & $\begin{array}{l}\text { Malta- } \\
2003\end{array}$ & $\begin{array}{l}\text { Malta- } \\
2004\end{array}$ \\
\hline & $\mathrm{kg} \mathrm{ha}^{-\mathrm{l}}$ & 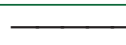 & 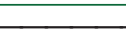 & 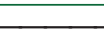 & $\mathrm{kg}$ & 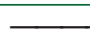 & & & \\
\hline \multirow[t]{8}{*}{ Upper slopes } & 0 & 2027 & 2933 & 1189 & 862 & 2394 & 2134 & 1312 & 2750 \\
\hline & 22 & 2218 & 2825 & $|22|$ & - & 2520 & 2247 & 1477 & 2764 \\
\hline & 37 & - & - & - & 725 & - & - & - & - \\
\hline & 45 & 2390 & 3048 & $1|7|$ & - & 2529 & 2301 & 1386 & 2881 \\
\hline & 67 & 2448 & 3563 & 1159 & - & 2492 & 2374 & 1427 & 2869 \\
\hline & 75 & - & - & - & 782 & - & - & - & - \\
\hline & 90 & 2325 & 3389 & $|15|$ & - & 2445 & 2203 & - & - \\
\hline & 112 & 2424 & - & - & 750 & - & - & - & - \\
\hline \multirow{8}{*}{$\begin{array}{l}\text { North-facing } \\
\text { middle slopes }\end{array}$} & 0 & 2367 & 3114 & 1003 & 885 & 2397 & 1915 & 1442 & 2806 \\
\hline & 22 & 2398 & 2954 & 1064 & - & 2455 & 2186 & 1554 & 2769 \\
\hline & 37 & - & - & - & 871 & - & - & - & - \\
\hline & 45 & 2445 & 3621 & 1053 & - & 2468 & 2207 & 1446 & 2894 \\
\hline & 67 & 2382 & 3528 & 1023 & - & 2420 & 2203 & 1420 & 2895 \\
\hline & 75 & - & - & - & 871 & - & - & - & - \\
\hline & 90 & 2278 & 3377 & 1027 & - & 2456 & 2167 & - & - \\
\hline & 112 & 2337 & - & - & 775 & - & - & - & - \\
\hline \multirow{8}{*}{$\begin{array}{l}\text { South facing- } \\
\text { middle slopes }\end{array}$} & 0 & 2257 & $3|5|$ & 1010 & 852 & 2347 & 1963 & 1327 & 2611 \\
\hline & 22 & 2343 & 3264 & 1073 & - & 2483 & 1925 & 1346 & 2607 \\
\hline & 37 & - & - & - & 703 & - & - & - & - \\
\hline & 45 & 2512 & 3388 & 1066 & - & 2495 & 1971 & 1398 & 2594 \\
\hline & 67 & 2526 & 3686 & 1038 & - & 2601 & 2067 & $138 \mid$ & 2711 \\
\hline & 75 & - & - & - & 760 & - & - & - & - \\
\hline & 90 & 2498 & 3477 & 1019 & - & 2403 & 1932 & - & - \\
\hline & 112 & 2501 & - & - & 692 & - & - & - & - \\
\hline \multirow[t]{8}{*}{ Lower slopes } & 0 & 2718 & 3423 & 1027 & 838 & 2389 & 1691 & 1933 & 2788 \\
\hline & 22 & 2738 & 3611 & 1015 & - & 2394 & 1808 & 1508 & 2749 \\
\hline & 37 & - & - & - & 824 & - & - & - & - \\
\hline & 45 & 2906 & 3739 & 1079 & - & 2562 & 1872 & 1686 & 2861 \\
\hline & 67 & 2700 & 3938 & 942 & - & 2593 & 1799 & 1813 & 2963 \\
\hline & 75 & - & - & - & 797 & - & - & - & - \\
\hline & 90 & 2600 & 3819 & 1018 & - & 2576 & 1679 & - & - \\
\hline & 112 & 2564 & - & - & 792 & - & - & - & - \\
\hline \multicolumn{10}{|c|}{ Ordinary ANOVA } \\
\hline $\mathrm{N}$ rate & & 0.017 & 0.002 & 0.308 & 0.063 & 0.117 & 0.014 & 0.699 & 0.031 \\
\hline $\mathrm{MZ}$ & & 0.000 & 0.000 & 0.000 & 0.025 & 0.012 & 0.000 & 0.000 & 0.000 \\
\hline $\mathrm{N}$ rate $\times \mathrm{MZ}$ & & 0.139 & 0.998 & 0.105 & 0.786 & 0.906 & 0.125 & 0.850 & 0.749 \\
\hline \multicolumn{10}{|c|}{ Autoregressive response based ANOVA } \\
\hline$\rho$ & & 0.000 & 0.000 & 0.000 & 0.000 & 0.000 & 0.000 & 0.000 & 0.000 \\
\hline $\mathrm{N}$ rate & & 0.007 & 0.021 & 0.178 & 0.065 & 0.149 & 0.020 & 0.308 & 0.014 \\
\hline$M Z$ & & 0.278 & 0.131 & 0.012 & 0.196 & 0.479 & 0.000 & 0.009 & 0.013 \\
\hline $\mathrm{N}$ rate $\times M Z$ & & 0.447 & 0.999 & 0.025 & 0.773 & 0.693 & 0.130 & 0.399 & 0.802 \\
\hline
\end{tabular}

Applying $\mathrm{N}$ using the variable-rate strategy consistently decreased farm profitability by up to US $\$ 56 \mathrm{ha}^{-1}$ for upper and north-facing middle slopes at all eight sites. In most instances, the reduction in profit with VNM was a result of lower yields relative to uniform $\mathrm{N}$ and higher costs. Net returns from variable-rate placement were mostly negative for south-facing middle and lower slope positions. The additional $\mathrm{N}$ that was applied by VNM mostly increased grain quality and yield but not enough to offset the added fixed and variable costs of this practice. An increase in the cost of fertilizer $\mathrm{N}$ would be expected to decrease benefits from VNM further.

Overall, net returns from VNM vs. UNM were negative and unfavorable $\left(>-\mathrm{US} \$ 28 \mathrm{ha}^{-1}\right)$ at all sites except Simpson-1994, where the net return was US $\$ 14 \mathrm{ha}^{-1}$. At
Simpson-1994, differences in net return between UNM and VNM in south-facing middle slopes were sufficient to offset the costs and revenue losses in the remaining three MZs. When EQIP payments were included, variable-rate $\mathrm{N}$ fertilization based on zone sampling and university $\mathrm{N}$ recommendations was only profitable at Simpson-1994. However, EQIP payments are sufficient to cover only 202 ha per farm. Unless these acreage limits are expanded, only about one-fifth as much per hectare is available for a typical 1100-ha farm. Overall, these results are in contrast to those of Beckie et al. (1997), who found enhanced fertilizer use efficiency and improved economic returns when varying fertilizer $\mathrm{N}$ rates according to topography in hummocky, glaciated terrain of northern Saskatchewan, where more fertilizer N is required. 
Table 8. Partial budget results for variable-rate N management (VNM) on eight site-years of dark northern spring wheat in northern Montana.

\begin{tabular}{|c|c|c|c|c|c|c|c|c|}
\hline Item & $\begin{array}{c}\text { Simpson- } \\
1994\end{array}$ & $\begin{array}{c}\text { Simpson- } \\
1995\end{array}$ & $\begin{array}{l}\text { Highwood- } \\
2001\end{array}$ & $\begin{array}{l}\text { Havre- } \\
2001\end{array}$ & $\begin{array}{l}\text { Malta- } \\
2001\end{array}$ & $\begin{array}{l}\text { Malta- } \\
2002\end{array}$ & $\begin{array}{l}\text { Malta- } \\
2003\end{array}$ & $\begin{array}{c}\text { Malta- } \\
2004\end{array}$ \\
\hline \multicolumn{9}{|c|}{ US\$ ha-l } \\
\hline \multicolumn{9}{|c|}{$\underline{\text { Upper slopes }}$} \\
\hline$\Delta$ Yield & 0.00 & -34.83 & 0.00 & 0.00 & -20.75 & 0.00 & -16.48 & 0.00 \\
\hline$\Delta$ Grain value & 0.00 & 0.00 & 0.00 & 0.00 & -18.67 & 0.00 & 0.00 & 0.00 \\
\hline VNM costs & 8.53 & 8.53 & 8.53 & 8.53 & 8.53 & 8.53 & 8.53 & 8.53 \\
\hline $\mathrm{N}$ costs & 0.00 & -20.12 & 0.00 & 0.00 & -19.24 & 0.00 & 20.12 & 0.00 \\
\hline Sampling costs & 4.15 & 7.17 & 4.85 & 6.11 & 7.50 & 5.50 & 11.00 & 6.35 \\
\hline Net return & -12.68 & $-30.4 I$ & -13.38 & -14.64 & -36.21 & -14.03 & -56.13 & -14.88 \\
\hline \multicolumn{9}{|c|}{$\underline{\text { North-facing middle slopes }}$} \\
\hline$\Delta$ Yield & 0.00 & -14.53 & 0.00 & 0.00 & -9.70 & 0.00 & 0.00 & 22.64 \\
\hline$\Delta$ Grain value & 0.00 & 0.00 & 0.00 & 0.00 & -18.46 & 0.00 & 0.00 & 4.34 \\
\hline VNM costs & 8.53 & 8.53 & 8.53 & 8.53 & 8.53 & 8.53 & 8.53 & 8.53 \\
\hline $\mathrm{N}$ costs & 0.00 & -20.12 & 0.00 & 0.00 & -19.24 & 0.00 & 0.00 & 20.12 \\
\hline Sampling costs & 4.15 & 7.17 & 4.85 & 6.11 & 7.50 & 5.50 & 11.00 & 6.35 \\
\hline Net return & -12.68 & $-|0| \mid$. & -13.38 & -14.64 & -24.95 & I 4.03 & -19.53 & -8.02 \\
\hline \multicolumn{9}{|c|}{$\underline{\text { South-facing middle slopes }}$} \\
\hline$\Delta$ Yield & 29.82 & -19.37 & $-|2.3|$ & 0.00 & 2.16 & 8.33 & 9.42 & -2.35 \\
\hline$\Delta$ Grain value & 50.99 & 0.00 & 0.00 & 0.00 & 7.73 & 0.00 & 0.00 & 0.00 \\
\hline VNM costs & 8.53 & 8.53 & 8.53 & 8.53 & 8.53 & 8.53 & 8.53 & 8.53 \\
\hline$N$ costs & 20.12 & 19.24 & 32.36 & 0.00 & 20.12 & 20.12 & 20.12 & 20.12 \\
\hline Sampling costs & 4.15 & 7.17 & 4.85 & 6.11 & 7.50 & 5.50 & 11.00 & 6.35 \\
\hline Net return & 48.01 & -54.31 & -58.05 & -14.64 & -26.26 & -25.82 & -30.23 & -37.35 \\
\hline \multicolumn{9}{|c|}{$\underline{\text { Lower slopes }}$} \\
\hline$\Delta$ Yield & -6.88 & 31.50 & -0.91 & -2.17 & 30.42 & 0.00 & 20.46 & 20.28 \\
\hline$\Delta$ Grain value & 49.95 & 8.27 & 0.00 & 0.00 & 7.69 & 0.00 & 0.00 & 0.00 \\
\hline VNM costs & 8.53 & 8.53 & 8.53 & 8.53 & 8.53 & 8.53 & 8.53 & 8.53 \\
\hline $\mathrm{N}$ costs & 39.36 & 19.24 & 32.36 & 19.24 & 20.12 & 0.00 & -19.24 & 20.12 \\
\hline Sampling costs & 4.15 & 7.17 & 4.85 & 6.11 & 7.5 & 5.50 & 11.00 & 6.35 \\
\hline Net return & -8.97 & 4.83 & -46.74 & -36.05 & 1.96 & -14.03 & 20.17 & -14.72 \\
\hline \multicolumn{9}{|c|}{ Weighted mean net return } \\
\hline Total† & 14.05 & -27.97 & -22.16 & -21.92 & -24.25 & -17.46 & -23.54 & -20.13 \\
\hline Total-EQIP $\ddagger$ & 20.41 & $-21.6 \mid$ & -15.80 & -15.56 & -17.89 & -11.10 & -17.18 & -13.77 \\
\hline
\end{tabular}

$\dagger$ Mean net return weighted by percentage of management zone area.

$\ddagger$ Weighted mean net return with USDA-NRCS Environmental Quality Incentive Payment.

\section{Economically Optimum Nitrogen Rates and Sensitivity Analysis}

The $\mathrm{N}$ rates that would have optimized net returns were identified based on the $\mathrm{N}$ responses of a site and its MZs (Table 7) and the last increment of $\mathrm{N}$ that gave the largest net return. These economically optimal $\mathrm{N}$ rates can be used to gauge the economic performance of variable-rate $\mathrm{N}$ management based on yield potentials and limited soil test information before planting. The results indicated VNM returning between US\$4and US\$20 ha less than UNM (data not shown). Apparently, VNM was less profitable because of no yield benefit or $\mathrm{N}$ cost reduction. Except for Simpson-1994, returns from VNM were between US\$1 and US $\$ 14 \mathrm{ha}^{-1}$ less than that of UMN when EQIP payments were available to help offset the added costs.

Variable rate $\mathrm{N}$ management must accurately match $\mathrm{N}$ requirements to crop $\mathrm{N}$ demands for this practice to be profitable. Unfortunately, most of the $\mathrm{N}$ recommendations did not agree with the optimal rates of $\mathrm{N}$ fertilizer, probably because of the aforementioned difficulty with predicting the influence of weather on crop $\mathrm{N}$ response. Of the $16 \mathrm{~N}$ management scenarios, comprising both $\mathrm{N}$ management systems across eight fields, four had $\mathrm{N}$ recommendations that were optimal, four were less than optimal, and eight were greater than optimal (Fig. 3). Net returns were negative due to underfertilization and lower yields when the recommended $\mathrm{N}$ rate was less than the optimal $\mathrm{N}$ rate. In addition, net returns were negative when the recommended $\mathrm{N}$ rate exceeded the optimal $\mathrm{N}$ rate because of the additional $\mathrm{N}$ fertilizer costs without an accompanying yield improvement.

Recently, Whelan et al. (2012) used a randomized, replicated "small strip" experimental design to obtain site-specific information about optimum $\mathrm{N}$ response within management zones of dryland fields. Multiple experiments were conducted for six seasons in three regions of the Australian Wheat Belt. Management zones were derived from maps of apparent electrical conductivity and historical yield maps. The optimal $\mathrm{N}$ rate for each zone was used to compute the potential gross margin from VNM for comparison with that achieved from UNM. Results on crop yield response to $\mathrm{N}$ showed that the difference in net return always favored VNM even when the $\mathrm{N}$ response functions were relatively flat and returns were expected to be poor in years of below-average rainfall. Their results suggested that economic benefits can be derived from VNM through the optimization of fertilizer application rates.

A sensitivity analysis was conducted to show the effect of various HRSW prices and changes in grain yield on net return in the 
Table 9. Sensitivity of net return to changes $(\Delta)$ in grain yield, wheat price from US $\$ 0.1248$ to US $\$ 0.4 I I 2$, and protein premium for variable-rate $N$ management for the Simpson-1994 site-year.

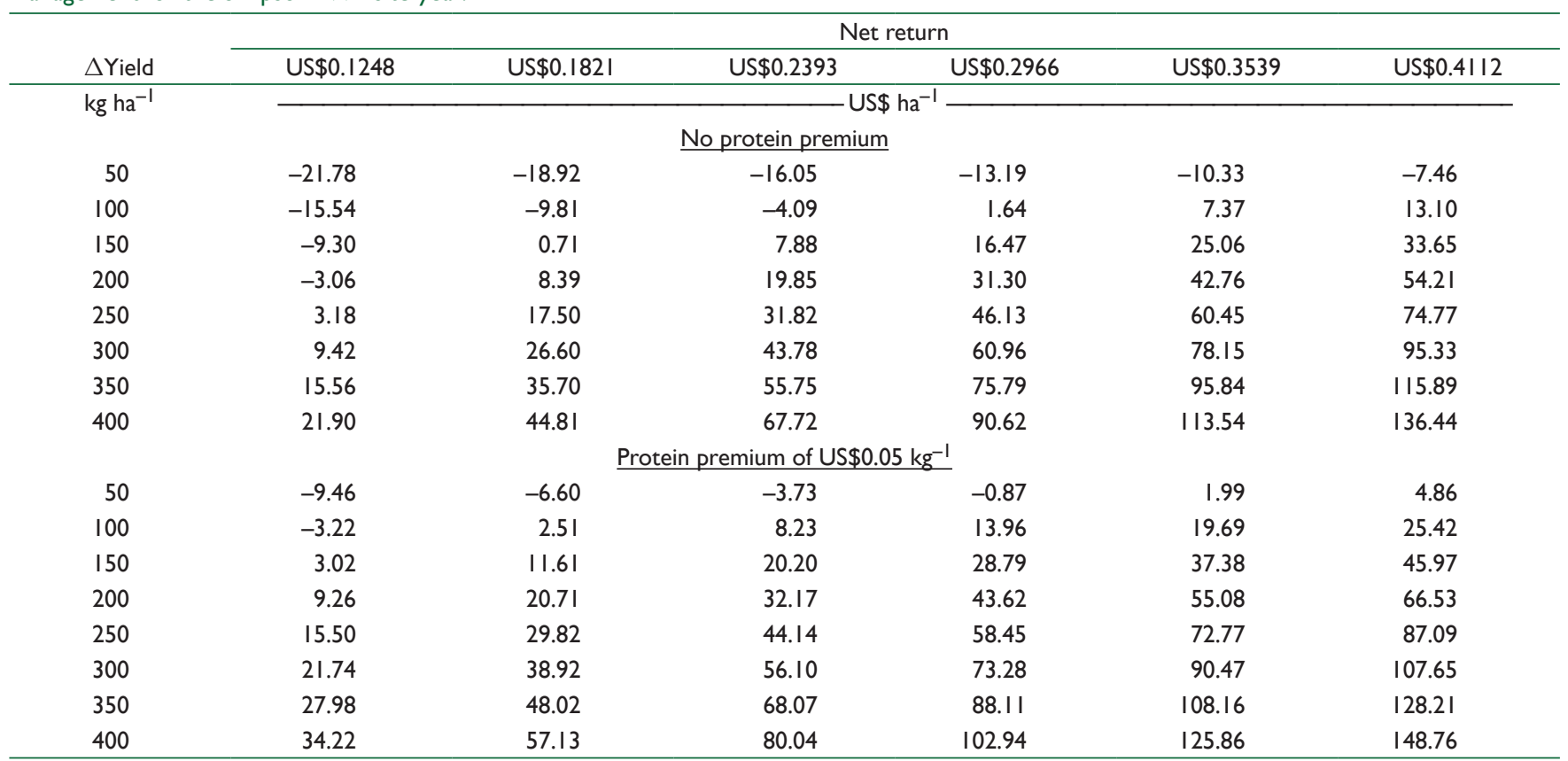

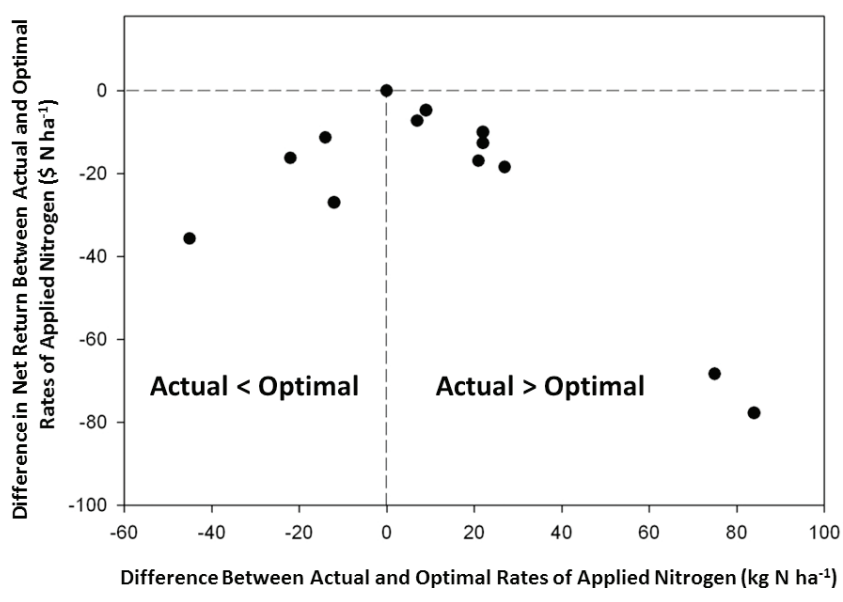

Fig. 3. Difference between actual and economically optimal rates of applied $\mathrm{N}$ vs. the difference in net return between actual and optimal rates of applied $\mathrm{N}$.

most profitable site-year (Simpson-1994; Table 9). Grain prices ranged from US $\$ 0.125 \mathrm{~kg}^{-1}$ (US\$3.40 bu ${ }^{-1}$ ) to US $\$ 0.411 \mathrm{~kg}^{-1}$ (US\$11.18 bu ${ }^{-1}$ ) to capture extremes in market variability since 1999. Likewise, the change in grain yield ranged up to $400 \mathrm{~kg} \mathrm{ha}^{-1}$ to indicate potential year-to-year variability. Positive net returns are generated when the yield change is $\geq 250 \mathrm{~kg} \mathrm{ha}^{-1}$ at the relatively low grain price of US $\$ 0.125 \mathrm{~kg}^{-1}$ but are also possible from changes in yield as small as $\geq 50 \mathrm{~kg} \mathrm{ha}^{-1}$ if grain prices are sufficiently large. Returns are also shown to be positive for prices $\geq \mathrm{US} \$ 0.125 \mathrm{~kg}^{-1}$ and yield changes $\geq 50 \mathrm{~kg} \mathrm{ha}^{-1}$.

\section{SUMMARY AND CONCLUSIONS}

A partial budget analysis of field-size strip trials with dryland HRSW at eight locations in northern Montana found that VNM utilizing conventional soil tests, fertilizer $\mathrm{N}$ recommendations, and terrain-based MZs was not more profitable than UNM. The reasons can be traced to modest yield gains and $\mathrm{N}$ savings, nominal response to fertilizer $\mathrm{N}$, and the inability to define $\mathrm{MZs}$ and optimal N rates. Gross returns were largely a function of grain yield. If EQIP payments were included as a part of gross returns, VNM was still not more profitable than UNM at seven of the eight sites. Based on sensitivity analysis, VRN would generate greater net returns than UNM only with higher grain prices, in fields and growing seasons with larger yield potentials than found in this study, or both.

Varying $\mathrm{N}$ rates according to $\mathrm{MZ}$ based strictly on terrain analysis and soil available $\mathrm{N}$ levels may not be useful for land managers in semiarid landscapes who would like to conduct VNM based on an association between landscape position and soil water availability. Integrating terrain data with agronomic information (e.g., sequential yield maps, remotely sensed imagery, and farmer knowledge) might have better delineated MZs and contributed to greater crop $\mathrm{N}$ response than was found in this experiment. Clearly, a precise VNM method is needed to overcome the difficulties associated with drought and modest grain yields in the summer-fallow system of the semiarid northern Great Plains.

\section{ACKNOWLEDGMENTS}

The authors acknowledge the Montana Wheat and Barley Committee, Montana Fertilizer Tax Fund Advisory Committee, Westco Fertilizers, and USDA-IFAFS (Grant no. 2001-52103-11321) for external funding support, and Willard and Karla Vaughn, Mark and Nancy Peterson, Ed Bumgarner, Les and Terry Kaercher, Karl and Bud Mavencamp, and Wes Anderson for access to their fields. The technical assistance of Gregg R. Carlson, Terry Grass, and Tom Allen is also appreciated. Special thanks to Dr. David Buschena in the planning of the experimental design and economic analysis.

\section{REFERENCES}

Beckie, H.J., A.P. Moulin, and D.J. Pennock. 1997. Strategies for variable rate nitrogen fertilization in hummocky terrain. Can. J. Soil Sci. 77:589-595. doi:10.4141/S96-095

Biermacher, J.T., F.M. Epplin, B.W. Brorsen, J.B. Solie, and W.R. Raun. 2006. Maximum benefit of a precise nitrogen application system for wheat. Precis. Agric. 7:193-204. doi:10.1007/s11119-006-9017-6 
Biermacher, J.T., F.M. Epplin, B.W. Brorsen, J.B. Solie, and W.R. Raun. 2009. Economic feasibility of site-specific optical sensing for managing nitrogen fertilizer for growing wheat. Precis. Agric. 10:213-230. doi:10.1007/ s11119-008-9092-y

Boyer, C.N., B.W. Brorsen, J.B. Solie, and W.R. Raun. 2011. Profitability of variable rate nitrogen application in wheat production. Precis. Agric. 12:473-487. doi:10.1007/s11119-010-9190-5

Brown, P.L., and G.R. Carlson. 1990. Grain yields related to stored water and growing season rainfall. Rep. 35. Montana Agric. Exp. Stn., Montana State Univ., Bozeman.

Campbell, C.A., D.R. Cameron, W. Nicholiachuk, and H.R. Davidson. 1977. Effects of fertilizer $\mathrm{N}$ and soil moisture on growth, $\mathrm{N}$ content, and moisture use by spring wheat. Can. J. Soil Sci. 57:289-310. doi:10.4141/cjss77-035

Carr, P.M., G.R. Carlson, J.S. Jacobsen, G.A. Nielsen, and E.O. Skogley. 1991. Farming soils, not fields: A strategy for increasing fertilizer profitability. J. Prod. Agric. 4:57-61. doi:10.2134/jpa1991.0057

Eitel, J.U.H., D.S. Long, P.E. Gessler, E.R. Hunt, Jr., and D.J. Brown. 2009. Sensitivity of ground-based remote sensing estimates of wheat chlorophyll content to variation in soil reflectance. Soil Sci. Soc. Am. J. 73:1715-1723. doi:10.2136/sssaj2008.0288

Engel, R.E., D.S. Long, and G.R. Carlson. 2001. Nitrogen requirements and yield potential of spring wheat as affected by water. Fertilizer Fact Sheet 25. Montana State Univ. Agric. Exp. Stn., Bozeman. http://andresources.montana.edu/ fertilizerfacts/documents/FF25WaterNSWYieldPotential.pdf (verified 17 June 2014).

Ferguson, R.B., and G.W. Hergert. 2009. Soil sampling for precision agriculture. Circ. EC154. Univ. of Nebraska Ext. Serv., Lincoln, NE. http://www.ianrpubs.unl. edu/epublic/live/ec154/build/ec154.pdf(verified 11 Aug. 2014).

Fiez, T., B. Miller, and W. Pan. 1994. Assessment of spatially variable nitrogen fertilizer management in winter wheat. J. Prod. Agric. 7:86-93. doi:10.2134/ jpa1994.0086

Franzen, D. 2008. Developing zone soil sampling maps. Publ. SF-1176-2. North Dakota State Univ. Ext. Serv., Fargo, ND. http://www.ag.ndsu.edu/pubs/ plantsci/soilfert/sf1176-2.pdf(verified 17 June 2014).

Gregorich, E.G., and D.W. Anderson. 1985. Effects of cultivation and erosion on the soils of four toposequences in the Canadian prairies. Geoderma 36:343-354. doi:10.1016/0016-7061(85)90012-6

Griffith, D.A. 1993. Spatial regression analyses on the PC: Spatial statistics using SAS. Am. Assoc. Geogr., Washington, DC.

Griffith, D.A., and P.R. Peres-Neto. 2006. Spatial modeling in ecology: The flexibility of eigenfunction spatial analyses. Ecology 87:2603-2613. doi:10.1890/0012-9658(2006)87[2603:SMIETF]2.0.CO;2

Jones, C., and J. Jacobsen. 2001. Nitrogen cycling, testing and fertilizer recommendations. Nutrient Manage. Module 3. Montana State Univ. Ext. Serv., Bozeman. http://landresources.montana.edu/nm/documents/NM3. pdf(verified 17 June 2014).

Koch, B., R. Khosla, W.M. Frasier, D.G. Westfall, and D. Inman. 2004. Economic feasibility of variable-rate nitrogen application utilizing site-specific management zones. Agron. J. 96:1572-1580. doi:10.2134/agronj2004.1572

Larson, W.E., and P.C. Robert. 1991. Farming by soil. In: R. Lal and F.J. Pierce, editors, Soil management for sustainability. Soil Water Conserv. Soc., Ankeny, IA. p. 103-112.

Long, D.S., C. Meier, R.E. Engel, and A. Lenssen. 2002. Landscape elements as a basis for nitrogen management zones in Montana. In: A.J. Schlegel, editor, Proceedings of the Great Plains Soil Fertility Conference, Denver, CO. 5-6 Mar. 2002. Kansas State Univ., Manhattan, KS. p. 46-52.

Lowenberg-DeBoer,J.2000. Estimating precision farming benefits. In: J. LowenbergDeBoer and K. Erickson, editors, Precision farming profitability. Purdue Univ., West Lafayette, IN. p. 5-11.

MacMillan, R.A. 2003. LandMapR Software Toolkit- C++ version: User's manual. LandMapper Environmental Solutions, Edmonton, AB. https://code.google.com/p/open-geomorphometry-project/downloads/ detail?name=LandMapR_C\%2B\%2B_User_Manual.pdf\&can=2\&q= (verified 27 Aug. 2014).
MacMillan, R.A., W.W. Pettapiece, S.C. Nolan, and T.W. Goddard. 2000. A generic procedure for automatically segmenting landforms into landform elements using DEM's, heuristic rules and fuzzy logic. Fuzzy Sets Syst. 113:81-109. doi:10.1016/S0165-0114(99)00014-7

Moore, I.D., P.E. Gessler, G.A. Nielsen, and G.A. Peterson. 1993. Soil attribute predictions using terrain analysis. Soil Sci. Soc. Am. J. 57:443-457. doi:10.2136/sssaj1993.03615995005700020026x

Moulin, A.P., D.W. Anderson, and M. Mellinger. 1994. Spatial variability of wheat yield, soil properties and erosion in hummocky terrain. Can. J. Soil Sci. 74:219-228. doi:10.4141/cjss94-030

Mulvaney, R.L. 1996. Nitrogen-Inorganic forms. In: D.L. Sparks, editor, Methods of soil analysis. Part 3. Chemical methods. SSSA Book Ser. 5. ASA and SSSA, Madison, WI. p. 1123-1184. doi:10.2136/sssabookser5.3.c38

National Agricultural Statistics Service. 2009. 2007 Census of agriculture. Vol. 1. Montana state and county data. USDA-NASS, Washington, DC. http:// www.agcensus.usda.gov/Publications/2007/Full_Report/Volume_1, Chapter_2_County_Level/Montana/st30_2_008_008.pdf (verified ${ }^{-} 1 \overline{7}$ June 2014).

National Agricultural Statistics Service. 2010. 2009 wheat chemical use. [Database.] http://www.nass.usda.gov/Data_and_Statistics/Pre-Defined_ Queries/2009_Wheat_Chem_Usage/index.asp (verified 8 Aug. 2014).

Nolan, S.C., T.W. Goddard, D.J. Heaney, D.C. Penney, and R.C. McKenzie. 1995. Effects of fertilizer on yield at different soil landscape positions. In: P.C. Robert et al., editor, Proceedings of the 2 nd International Conference on Site-Specific Management for Agricultural Systems, Minneapolis, MN. 27-30 Mar. 1994. ASA, CSSA, and SSSA, Madison, WI. p. 553-558. doi:10.2134/1995.sitespecificmanagement.c39

North Dakota Wheat Commission. 2013. U.S. hard red spring wheat: 2013 regional quality report. http://ndwheat.com/uploads/resources/917/final-oct-21.pdf (verified 17 June 2014).

Pennock, D.J., and M.D. Corre. 2001. Development and application of landform segmentation procedures. Soil Tillage Res. 58:151-162. doi:10.1016/ S0167-1987(00)00165-3

Raun, W.R., J.B. Solie, G.V.Johnson, M.L. Stone, R.W. Mullen, K.W. Freeman, et al. 2002. Improving nitrogen use efficiency in cereal grain production with optical sensing and variable rate application. Agron. J. 94:815-820. doi:10.2134/ agronj2002.8150

Schepers, A.R., J.F. Shannahan, M.A. Liebig, J.S. Schepers, S.H. Johnson, and A. Luchiari, Jr. 2004. Appropriateness of management zones for characterizing spatial variability of soil properties and irrigated corn yields across years. Agron. J. 96:195-203. doi:10.2134/agronj2004.0195

Schumacher, T.E., M.J. Lindstrom, J.A. Schumacher, and G.D. Lemme. 1999. Modeling spatial variation in productivity due to tillage and water erosion. Soil Tillage Res. 51:331-339. doi:10.1016/S0167-1987(99)00046-X

Snyder, C., J. Havlin, G. Kluitenberg, and T. Schroeder. 1999. Evaluating the economics of precision agriculture. In: P.C. Robert et al., editor, Proceedings of the 4th International Conference on Precision Agriculture. St. Paul, MN. 19-22 July 1998. ASA, CSSA, and SSSA, Madison, WI. p. 1621-1632. doi:10.2134/1999.precisionagproc4.c67b

Snyder, C., T.Schroeder,J.Havlin, and G. Kluitenberg. 1997. An economic analysis of variable-rate nitrogen management. In: P.C. Robert et al., editor, Proceedings of the 3rd International Conference on Precision Agriculture, Minneapolis, MN. 23-26 June 1996. ASA, CSSA, and SSSA, Madison, WI. p. 989-998. doi:10.2134/1996.precisionagproc3.c122

Terman, G.L., R.E. Ramig, A.F. Dreier, and R.A. Olson. 1969. Yield-protein relationships in wheat grain as affected by nitrogen and water. Agron. J. 61:755-759. doi:10.2134/agronj1969.00021962006100050031x

Upton, G.J.G., and B. Fingleton. 1985. Spatial data analysis by example. Vol. I. Point pattern and quantitative data. John Wiley \& Sons, New York.

Whelan, B.M., J.A. Taylor, and A.B. McBratney. 2012. A 'small strip' approach to empirically determining management class yield response functions and calculating the potential financial 'net wastage' associated with whole-field uniform-rate fertilizer application. Field Crops Res. 139:47-56. doi:10.1016/j. fcr.2012.10.012

Wibawa, W.D., D.L. Dludlu, L.J. Swenson, D.G. Hopkins, and W.C. Dahnke. 1993. Variable fertilizer application based on yield goal, soil fertility, and soil map unit. J. Prod. Agric. 6:255-260. doi:10.2134/jpa1993.0255 